\title{
Evaluation of coat color inheritance and production performance for crossbreed from Chinese indigenous Chenghua pig crossbred with Berkshire
}

\author{
Yujing Li ${ }^{1, a}$, Rong Yuan ${ }^{2, a}$, Zhengyin Gong ${ }^{1}$, Qin Zou ${ }^{1}$, Yifei Wang ${ }^{1}$, Guoqing Tang ${ }^{3}$, \\ Li Zhu ${ }^{3}$, Xuewei $\mathrm{Li}^{3}$, and Yanzhi Jiang ${ }^{1, *}$
}

\footnotetext{
* Corresponding Author: Yanzhi Jiang Tel: +86-0835-2886103,

Fax: +86-0835-2886136,

E-mail: jiangyz04@163.com

' Department of Zoology, College of Life Science, Sichuan Agricultural University, Ya'an 625014, Sichuan, China ${ }^{2}$ Chengdu Livestock and Poultry Genetic Resources Protection Center, Chengdu 610081, Sichuan, China

${ }^{3}$ Institute of Animal Genetics and Breeding, College of Animal Science and Technology, Sichuan Agricultural University, Chengdu 611130, Sichuan, China
}

a These authors contributed equally to this work.

ORCID

Yujing Li

https://orcid.org/0000-0002-1589-0910 Rong Yuan

https://orcid.org/0000-0001-7055-7670

Zhengyin Gong

https://orcid.org/0000-0002-4019-9881 Qin Zou

https://orcid.org/0000-0001-7292-0680 Yifei Wang

https://orcid.org/0000-0001-9516-9113

Guoging Tang

https://orcid.org/0000-0001-9680-2857

Li Zhu

https://orcid.org/0000-0002-6611-0793 Xuewei Li

https://orcid.org/0000-0002-3498-5448

Yanzhi Jiang

https://orcid.org/0000-0002-9568-557X

Submitted Dec 28, 2021; Revised Feb 1, 2022; Accepted Mar 2, 2022
Objective: This work was to determine coat inheritance and evaluate production performance for crossbred pigs from Berkshire $\times$ Chenghua $(\mathrm{BC})$ compared with Chinese indigenous Chenghua $(\mathrm{CH})$ pigs.

Methods: The coat color phenotypes were recorded for more than 16,000 pigs, and the genotypes of melanocortin 1 receptor $(M C I R)$ gene were identified by sequencing. The reproductive performance of 927 crossbred BC F4 gilts and 320 purebred $\mathrm{CH}$ gilts was recorded. Sixty pigs of each breed were randomly selected at approximately 60 days of age to determine growth performance during fattening period, which lasted for 150 days for $\mathrm{BC}$ pigs and 240 days for $\mathrm{CH}$ pigs. At the end of the fattening period, 30 pigs of each breed were slaughtered to determine carcass composition and meat quality.

Results: The coat color of BC pigs exhibits a "dominant black" hereditary pattern, and all piglets derived from boars or sows genotyped $E^{D 1} E^{D 1}$ homozygous for $M C 1 R$ gene showed a uniform black coat phenotype. The BC F4 gilts displayed a good reproductive performance, showing a higher litter and tear size and were heavier at farrowing litter and at weaning litter than the $\mathrm{CH}$ gilts, but they reached puberty later than the $\mathrm{CH}$ gilts. BC F4 pigs exhibited improved growth and carcass characteristics with a higher average daily live weight gain, lower feed-to-gain ratio, and higher carcass lean meat rate than $\mathrm{CH}$ pigs. Like $\mathrm{CH}$ pigs, $\mathrm{BC}$ F4 pigs produced superior meat-quality characteristics, showing ideal $\mathrm{pH}$ and meat-color values, high intramuscular fat content and water-holding capacity, and acceptable musclefiber parameters. C18:1, C16:0, C18:0, and C18:2 were the main fatty acids in M. longissimus lumborum in the two breeds, and a remarkably high polyunsaturated/saturated fatty acid ratio of $\sim 0.39$ was observed in the $\mathrm{BC}$ F4 pigs.

Conclusion: The BC F4 pigs exhibit a uniform black coat pattern and acceptable total production performance.

Keywords: Berkshire; Chenghua Pig; Coat Color; Crossbred; Melanocortin 1 Receptor $(M C 1 R)$; Production Performance

\section{INTRODUCTION}

The Chenghua $(\mathrm{CH})$ pig is a traditional black breed native to southwestern China in Sichuan Province, and it is characterized by superior meat quality characteristics and good adaptability to extensive management [1]. However, due to undesirable attributes such as slow growth rate and low lean meat percentage [2], the production system of purebred $\mathrm{CH}$ pigs has been almost displaced, while $\mathrm{CH}$ pigs have been included in the National Program for Farm Animal Resources since 2014.

Crossbreeding programs have been used extensively to improve the native pig's overall 
production performance while maintaining superior meat quality for F1 hybrid pigs from Duroc $\times$ Dahe, Duroc or Landrace $\times$ Celta, Duroc $\times$ Korean Native Black Pig, and Duroc $\times$ Berkshire (BK) $\times$ Yanan [3-6]. However, due to the break-up of epistatic complexes since the F2 generation [7,8], improving and stabilizing the obtained heterosis based on breed additive and dominance effects is a considerable challenge for new breed formation arising from the crossing of two or more existing breeds.

In recent years, to utilize the genetic resource of the $\mathrm{CH}$ pig to improve its overall production performance and produce superior meat, we have implemented the crossbreeding scheme of $\mathrm{BK} \times \mathrm{CH}(\mathrm{BC})$ and bred the new crossbred $\mathrm{BC}$ pig through selection for four generations. Currently, the core breeding group of $\mathrm{BC}$ pigs contains 30 unrelated boar strains and more than 1,000 sows, and the production system of $\mathrm{BC}$ pigs can supply approximately 50,000 black fattening pigs per year to meet the market demand for high quality pork. However, scientific data evaluating the production performance and coat color variation for the new crossbred BC pigs is lacking. Therefore, the objective of this work was to determine the black coat inheritance and evaluate production performance for crossbred BC F4 pigs in comparison with the same assessments of control, purebred $\mathrm{CH}$ pigs.

\section{MATERIALS AND METHODS}

All animal experimental procedures were approved by the Instituional Animal Care and Use Committee of Sichuan Agricultural University (permit number: SKY-2021216012).

\section{Breeding group structure and management}

All pigs were maintained on the Qionglai Jialin Ecological Farm, Chengdu city, China. The core breeding group of purebred $\mathrm{CH}$ pigs included 8 unrelated boar strains and 320 sows. The $\mathrm{BC}$ crossbred base population derived from the progeny of $10 \mathrm{BK}$ unrelated boar strains and $218 \mathrm{CH}$ sows with the above sow selection index (SSI). The more advanced generations were bred by the method of population subgeneration breeding, and the crossbreeding population included 30 unrelated boar strains and approximately 600 sows in each generation. Mating was performed in a way that reduced inbreeding. Animals with a relationship coefficient above 5\% were not mated with each other. All mattings were performed through artificial insemination. The selection of boars and gilts was based mainly on the boar selection index (BSI) and SSI, respectively; meanwhile, the selection was also in combination with pedigree and phenotypic characteristics. The management and feeding conditions of all pigs at different stages of production were largely designed according to the conditions that are experienced in modern breeding areas. The diets met the National Research Council (NRC) [9] rec- ommendations for the different production phases.

The model fitted for the boar and SSI were:

$$
\begin{aligned}
& B S I=100+8.25 E B V_{W T 200}-4.78 E B V_{B F 200} \\
& S S I=100+20.35 E B V_{N B T}+4.62 E B V_{W T 200}-2.56 E B V_{B F 200}
\end{aligned}
$$

where $B S I$ is the boar selection index while $S S I$ is the sow selection index; $E B V_{W T 200}$ and $E B V_{B F 200}$ are the estimated breeding values for live weight and backfat thickness at 200 days of age, respectively; $E B V_{N B T}$ is the total number of pigs born per litter.

\section{Observation of coat color variation and collection of reproductive performance data}

Coat color was observed for cross piglets per litter and their parents, and "the uniform black" or "domino black spotting" phenotypes were recorded for more than 16,000 pigs. The reproductive performance of 927 crossbred BC F4 gilts and 320 purebred $\mathrm{CH}$ gilts was recorded and collected from January 2019 to July 2020. The number of teats was recorded for gilts, and the puberty of gilts was defined as the first observed estrus followed by a second estrus approximately 21 or $42 \mathrm{~d}$ later. The total number of pigs born and number of pigs born alive per litter were recorded, while piglets per litter were weighed within $12 \mathrm{~h}$ of birth and at $28 \mathrm{~d}$ of age for litter weight at birth and litter weight at weaning, respectively.

\section{Identification of MC1R single nucleotide polymorphisms}

Hairs with follicles were collected after disinfection with $75 \%$ alcohol at the shoulder, washed twice with phosphatebuffered saline and stored in a refrigerator at $-20^{\circ} \mathrm{C}$. Genomic DNA was extracted using a DNA extraction kit according to the manufacturer's instructions (Magen, Guangzhou, China). Two pairs of primers were designed according to the melanocortin 1 receptor $(M C 1 R)$ reference sequence (GenBank accession number FJ6655467.1) to amplify the complete MC1R DNA sequence (Table 1). The polymerase chain reaction (PCR) system was $25 \mu \mathrm{L}$, containing $22 \mu \mathrm{L} 2 \times$ TsingKE Master Mix (TsingKE, Beijing, China), $1 \mu \mathrm{L}$ upstream primer, $1 \mu \mathrm{L}$ downstream primer, and $1 \mu \mathrm{L}$ DNA. Thermocycling conditions began with denaturing at $98^{\circ} \mathrm{C}$ for $2 \mathrm{~min}$, followed by 34 cycles of denaturing at $98^{\circ} \mathrm{C}$ for $10 \mathrm{~s}$, annealing at the $\mathrm{Tm}$ (Table 1) for $10 \mathrm{~s}$, extension at $72^{\circ} \mathrm{C}$ for $10 \mathrm{~s}$, and finally extension at $72^{\circ} \mathrm{C}$ for $5 \mathrm{~min}$. The samples were stored at $4^{\circ} \mathrm{C}$. The amplification process was conducted using a Genemate Series PCR machine (Analytik Jena, Jena, Germany).

An aliquot of $5 \mu \mathrm{L}$ of PCR product was used for $1.5 \%$ agarose gel electrophoresis to determine whether the $M C 1 R$ gene was amplified. BigDye Terminator V3.1 was used for sequencing purification. A 3,730 sequencer was used for se- 
Table 1. Primer sequences and amplification conditions for the MC1R gene

\begin{tabular}{lclccc}
\hline Gene & Primer & Primer sequence & Binding region & Product size (bp) & Annealing temperature $\left({ }^{\circ} \mathbf{C}\right)$ \\
\hline MC1R & M-F1 & GCTGAGCACAGGCGAGGTT & 5 UTR & 884 & \\
& M-R1 & GGAAGCAGAGGCTGGACACC & Exon1 & & \\
& M-F2 & CATCGCCAAGAACCGCAACC & Exon1 & & \\
& M-R2 & GGTCCAGCGTCCATACCTTCA & 3'UTR & & \\
\hline
\end{tabular}

MC1R, melanocortin 1 receptor; UTR, untranslated regions.

quencing, and 3730XL was used for data collection. The sequencing sequence and peak graph were obtained by Chromas. The obtained sequence was spliced by CExpress to obtain a complete sequence. The sequence was aligned by BLAST in NCBI.

\section{Measurement of fattening and slaughtering performance}

In total, 120 pigs ( 30 castrated males and 30 females for BC $\mathrm{F} 4$ or $\mathrm{CH}$ pigs, respectively) were randomly selected at approximately 60 days of age (with weight at approximately 15 $\mathrm{kg}$ ). These pigs of each breed were born to a total of 15 litters that were produced by five sires and 15 sows. All pigs were housed in individual pens $\left(2 \mathrm{~m}^{2}\right)$ located in the same room and were fed twice a day with the same diet, and pigs had ad libitum access to diet and water (nipple drinkers). For the pigs to gain the expected market slaughter weight and age, the fattening experiment lasted for 150 days for BC pigs and 240 days for $\mathrm{CH}$ pigs after the 7 days adaptation period. The experimental diets met the National Research Council (NRC) [9] recommendations for the two different growth phases. In the fattening period, the data of initial live weight, final live weight and feed consumption were recorded to determine daily live weight gain and feed-to-gain ratio.

At the end of the fattening period, 30 pigs ( 15 castrated males and 15 females) of each breed were slaughtered to determine carcass-composition characteristics according to the described methods $[3,6]$. The measure carcass attributes included carcass length, dressing percentage, back fat thickness, loin muscle area, skin thickness, number of ribs, and dissection ratio of bone, muscle, subcutaneous fat and skin. The $M$. longissimus lumborum of the left side of the carcass at the last third to fourth rib was sampled and used to measure meat quality according to the described methods $[3,6]$. The measure meat quality properties included $\mathrm{pH}$ values, color parameters, water-holding capacity, and muscle fiber parameters. The muscular fatty acid (FA) composition was analyzed using gas chromatography (Agilent 6820, Agilent Technologies, Palo Alto, CA, USA) and capillary column (HP-Innowax, Agilent, $30 \mathrm{~m}$ long, $0.32 \mathrm{~mm}$ internal diameter, $0.25 \mathrm{~mm}$ film thickness) according to the described method [10].

\section{Statistical analyses}

Statistical testing was implemented by IBM SPSS Statistics 22 . The data are quantified as the mean \pm standard error of the mean for one group. The differences between groups were calculated using an independent $\mathrm{T}$ test. Statistical significance is defined when $p$ values are less than $0.05,{ }^{*} \mathrm{p}<0.05,{ }^{* *} \mathrm{p}<0.01$, and ${ }^{* *} \mathrm{p}<0.001$.

\section{RESULTS}

Specific black coat were selected for the crossbred BC pigs based on the $E^{D 1} E^{D 1}$ homozygous genotype of the $M C 1 R$ gene

To identify the hereditary pattern of black coat for the crossbred BC pigs, we first observed the phenotypic changes of coat color in cross generation. As a result, all F1 crosses $(3,140)$, which were derived from 10 BK boars (domino black spotting type) and $320 \mathrm{CH}$ sows (black type), were uniform black. However, F2 cross pigs $(5,906)$, which were derived from 30 F1 black boars and $588 \mathrm{~F} 1$ black sows, were black or domino in the proportion of approximately 3:1 (Figure 1). Interestingly, when $26 \mathrm{~F} 2$ black boars were used in the production system, F3 cross pigs (2, 038 out of 2,041) derived from 9 F2 black boars (called homozygote) and 182 F2 black sows were uniform black, but F3 cross pigs $(3,698)$ derived from the other 17 F2 black boars (called heterozygote) were black or domino in the proportion of approximately 5:1 (Table 2). The results indicated that the black coat of crossbred $\mathrm{BC}$ pigs might be controlled by a dominant single gene and could be inherited in accordance with Mendel's law of segregation.

Based on the important regulatory role of $M C I R$ gene on body melanin deposition [11], we considered the MC1R gene as a potential candidate gene for the black coat of crossbred $\mathrm{BC}$ pigs and cloned and sequenced the complete DNA of the $M C 1 R$ gene for these samples from $\mathrm{BK}, \mathrm{CH}, \mathrm{F} 1$ crosses, $\mathrm{F} 2$ black boars (homozygous or heterozygous), and F2 domino black spotting cross pigs. As a result, we obtained a 1,552 bp DNA sequence of MC1R (GenBank accession number AY 960624) and screened 12 mutation sites in the complete DNA sequence of the $M C 1 R$ gene from these samples (Table 3). According to the definitely established alleles at the MC1R locus [11], we found that the $\mathrm{CH}$ pigs and F2 black boars (homozygotes) showed the typical $E^{D 1} E^{D 1}$ homozygous geno- 
(a)

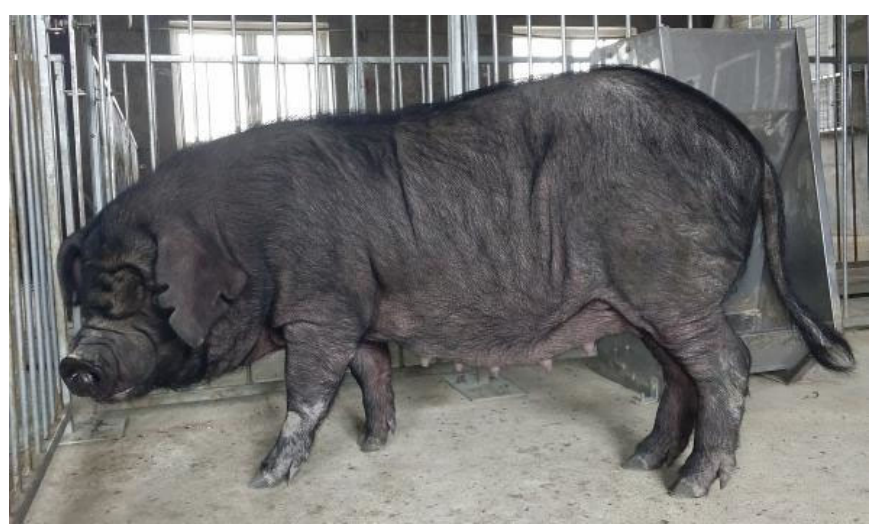

(c)

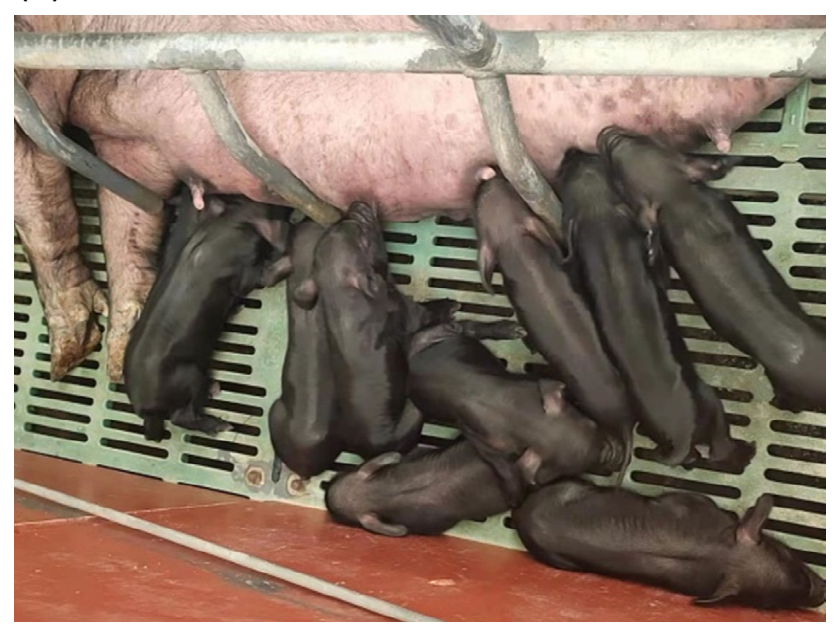

(b)

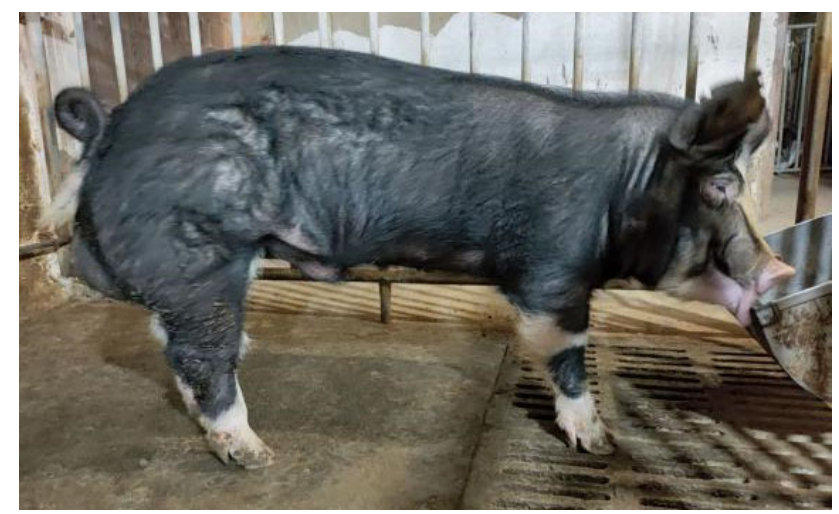

(d)

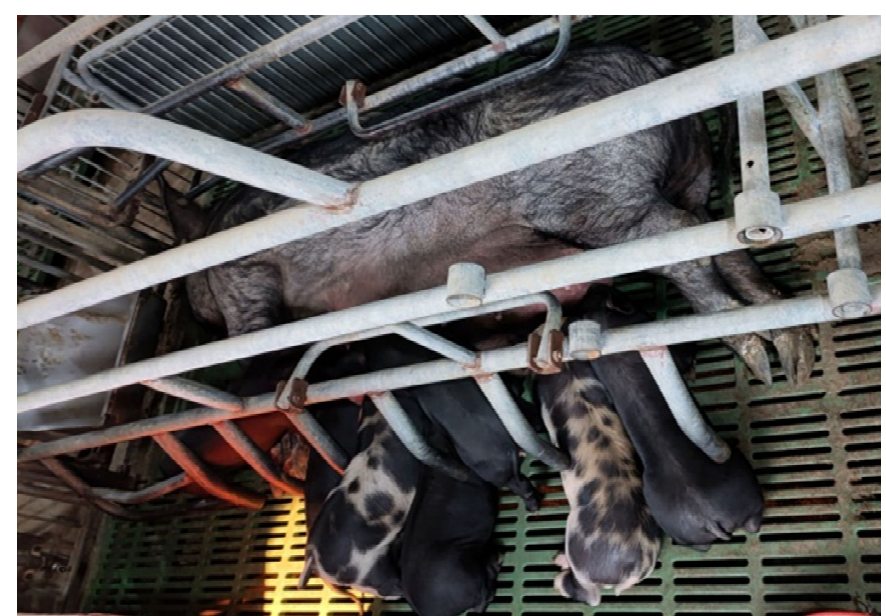

Figure 1. Phenotypic characteristics of hair color in different pig populations. (a) uniform black type for pure Chenghua pig; (b) domino black spotting type for Berkshire pig; (c) uniform black type for the cross F1 from BerkshirexChenghua (BC); (d) Color separation with black type and "black-white" type for the cross F2 from BerkshirexChenghua (BC).

type, while BS and F2 crosses with domino black spotting showed other opposite $E^{P} E^{P}$ homozygous genotypes; meanwhile, F1 crosses and F2 black boars (heterozygotes) displayed the same $E^{D 1} E^{P}$ heterozygous genotype (Table 3 ). This result indicates that the $E^{D 1}$ allele is associated with a black coat phenotype and is inherited in a dominant pattern in crossbred BC pigs. According to the above results, we selected black boars and sows genotyped with $E^{D 1} E^{D 1}$ from the F3 generation to reproduce offspring. As expected, all BC F4 cross pigs showed uniform black color in the whole production system.

\section{Reproductive performance of crossbred $\mathrm{BC}$ gilts} compared with purebred $\mathrm{CH}$ gilts

Table 4 summarizes the reproductive performance of crossbred $\mathrm{BC}$ F4 gilts compared with purebred $\mathrm{CH}$ gilts. The mean

Table 2. Observation of coat color variation in crossbred $\mathrm{BC}^{1)}$ pigs

\begin{tabular}{|c|c|c|c|c|c|c|c|}
\hline \multirow{3}{*}{$\begin{array}{l}\text { Progeny } \\
F 1^{2)}\end{array}$} & \multicolumn{2}{|c|}{ Boar } & \multicolumn{2}{|c|}{ Sow } & \multicolumn{3}{|c|}{ Piglets } \\
\hline & \multirow{2}{*}{$\begin{array}{c}\text { Breed } \\
\mathrm{BK}^{1)}(10)\end{array}$} & \multirow{2}{*}{$\begin{array}{c}\text { Coat color } \\
\text { Black }\end{array}$} & \multirow{2}{*}{$\frac{\text { Breed }}{\mathrm{CH}^{1)}(320)}$} & \multirow{2}{*}{$\begin{array}{c}\text { Coat color } \\
\text { Black }\end{array}$} & \multicolumn{2}{|c|}{ Coat color } & \multirow{2}{*}{ Ratio of black: domino } \\
\hline & & & & & Black (3140) & Domino (0) & \\
\hline F3 & F2 (9) & Black & F2 (182) & Black & Black (2038) & Domino (3) & - \\
\hline F3 & F2 (17) & Black & F2 (330) & Black & Black (3088) & Domino (610) & $5: 1$ \\
\hline
\end{tabular}

1) $\mathrm{BC}$, Berkshire $\times$ Chenghua; $\mathrm{BK}$, Berkshire; $\mathrm{CH}$, Chenghua.

${ }^{2)} \mathrm{F} 1, \mathrm{~F} 2$, and $\mathrm{F} 3$ means the $\mathrm{BC}$ cross pigs from first, second, and third generation, respectively.

"-" Means that the ratio cannot be calculated or very large because coat color pattern of (nearly) all pigs is black. 
Table 3. Mutation sites of the $M C 1 R$ gene in $\mathrm{CH}^{1)}, \mathrm{BK}^{1)}$, and crossbred $\mathrm{BC}^{1)}$ pigs

\begin{tabular}{|c|c|c|c|c|c|c|c|c|c|c|c|c|c|c|c|}
\hline \multirow{3}{*}{ Breed } & \multirow{3}{*}{ Coat color pattern } & \multirow{3}{*}{$\begin{array}{c}\text { Genotype } \\
\text { locus }\end{array}$} & \multirow{3}{*}{$\begin{array}{c}\text { Allele } \\
\text { /genotype }\end{array}$} & \multicolumn{12}{|c|}{ Mutation locus } \\
\hline & & & & \multicolumn{5}{|c|}{ 5'UTR } & \multicolumn{7}{|c|}{ CDS } \\
\hline & & & & 215 & 220 & 242 & 371 & 414 & 490 & 505 & 722 & 744 & 802 & 809 & 1338 \\
\hline \multirow[t]{2}{*}{$\mathrm{CH}, \mathrm{F} 2$} & Black & $E^{D 1} E^{D 1}$ & Allele & A & G & C & G & C & A & - & A & C & C & G & A \\
\hline & & & Genotype & $\mathrm{AA}$ & GG & $\mathrm{CC}$ & GG & CC & $A A$ & - & AA & $\mathrm{CC}$ & CC & GG & $\mathrm{AA}$ \\
\hline \multirow[t]{2}{*}{$F 1^{2)}, F 2^{2)}$} & Black & $E^{D 1} E^{P}$ & Allele & $A \& G$ & $A \& G$ & C\&T & $A \& G$ & C\&T & $A \& G$ & $-\mathrm{CC}$ & $A \& G$ & $C \& T$ & C\&T & $A \& G$ & $A \& G$ \\
\hline & & & Genotype & $A G$ & $A G$ & CT & $A G$ & CT & $A G$ & $-\mathrm{CC}$ & $A G$ & CT & CT & $A G$ & $A G$ \\
\hline \multirow[t]{2}{*}{$B K, F 2$} & Domino black spotting & $E^{P} E^{P}$ & Allele & G & A & $\mathrm{T}$ & A & $\mathrm{T}$ & G & $-\mathrm{CC}$ & G & $\mathrm{T}$ & $\mathrm{T}$ & A & G \\
\hline & & & Genotype & $\mathrm{GG}$ & $\mathrm{AA}$ & TT & AA & TT & $\mathrm{GG}$ & $-\mathrm{CC}$ & GG & TT & TT & AA & GG \\
\hline
\end{tabular}

MC1R, melanocortin 1 receptor; 5'UTR, 5'-untranslated regions; CDS, coding sequence.

1) $\mathrm{CH}$, Chenghua; $\mathrm{BK}$, Berkshire; $\mathrm{BC}$, Berkshire $\times$ Chenghua.

${ }^{2)} \mathrm{F} 1$ and $\mathrm{F} 2$ mean the $\mathrm{BC}$ cross pigs from first and second generation, respectively.

GenBank accession number AY960624.

Table 4. Reproductive performance of crossbred BC F4 gilts compared with purebred $\mathrm{CH}$ gilts

\begin{tabular}{|c|c|c|c|c|c|c|c|c|}
\hline \multirow{3}{*}{ Traits } & \multicolumn{6}{|c|}{ Breeds } & \multirow{3}{*}{ SEM } & \multirow{3}{*}{ p-value } \\
\hline & \multicolumn{3}{|c|}{$B C^{1)}(n=927)$} & \multicolumn{3}{|c|}{$\mathrm{CH}^{1)}(\mathrm{n}=322)$} & & \\
\hline & Mean & SD & CV (\%) & Mean & SD & CV (\%) & & \\
\hline Teat number & 13.45 & 1.21 & 9.00 & 12.14 & 0.87 & 7.17 & 0.03 & $\star \star \star$ \\
\hline Puberty age (d) & 168.44 & 28.38 & 16.85 & 125.45 & 21.39 & 17.05 & 2.60 & 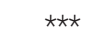 \\
\hline Total no. born & 12.36 & 2.13 & 17.23 & 10.31 & 2.01 & 19.50 & 0.07 & 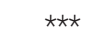 \\
\hline No. born alive & 11.64 & 1.74 & 15.62 & 9.82 & 1.88 & 19.14 & 0.03 & $\star \star \star$ \\
\hline Litter birth wt (kg) & 11.92 & 1.78 & 14.93 & 8.33 & 1.65 & 19.81 & 0.25 & $\star \star \star$ \\
\hline Litter weaning wt (kg) & 65.87 & 11.79 & 17.90 & 49.40 & 10.50 & 21.26 & 0.64 & 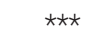 \\
\hline
\end{tabular}

SEM, standard error of the mean; SD, standard deviation; $C V$, coefficient of variation.

1) $\mathrm{BC}$, Berkshire $\times$ Chenghua; $\mathrm{CH}$, Chenghua.

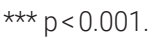

number of teats was higher for $\mathrm{BC}$ gilts than for $\mathrm{CH}$ gilts ( $\mathrm{p}<$ $0.001,13.45$ vs 12.14 ). The mean age at puberty of $\mathrm{BC}$ gilts was $168.44 \mathrm{~d}$, although it was older than that of $\mathrm{CH}$ gilts $(\mathrm{p}<0.001,125.45 \mathrm{~d})$. The total number of pigs born (12.36 pigs) and number of pigs born alive (11.64 pigs) per litter were higher $(\mathrm{p}<0.001)$ for $\mathrm{BC}$ sows than for $\mathrm{CH}$ sows $(10.31$ pigs and 9.82 pigs, respectively). Breed effects were significant for litter birth weight and litter weaning weight. At birth and weaning at $28 \mathrm{~d}$ of age, litters from BC sows $(11.92 \mathrm{~kg}$ and $65.87 \mathrm{~kg}$, respectively) were heavier $(\mathrm{p}<0.001)$ than those from $\mathrm{CH}$ sows ( $8.33 \mathrm{~kg}$ and $49.40 \mathrm{~kg}$, respectively).

\section{Growth and carcass attributes of crossbred BC pigs compared with purebred $\mathrm{CH}$ pigs}

As expected, throughout the fattening period, the crossbred $\mathrm{BC}$ F4 pigs grew faster than the purebred $\mathrm{CH}$ pigs $(\mathrm{p}<0.001)$, with a higher average daily live weight gain ( $645.28 \mathrm{~g}$ vs $447.11 \mathrm{~g}$ ); meanwhile, feed consumption was more efficient for $\mathrm{BC}$ crosses than for $\mathrm{CH}$ pigs ( $\mathrm{p}<0.001$, feed-to-gain ratio: 3.06 vs 4.03 ) (Table 5 ).

As shown in Table 5, the crossbred BC F4 pigs exhibited a superior carcass composition compared with those of purebred $\mathrm{CH}$ pigs. The slaughter weight was heavier for $\mathrm{BC}$ pigs at $211.70 \mathrm{~d}$ age than for $\mathrm{CH}$ pigs at $302.05 \mathrm{~d}$ of age $(\mathrm{p}<0.001$, $112.56 \mathrm{~kg}$ vs $105.00 \mathrm{~kg}$ ). The carcasses of $\mathrm{BC}$ pigs were longer than those of $\mathrm{CH}$ pigs ( $\mathrm{p}<0.001,83.35 \mathrm{~cm}$ vs $74.85 \mathrm{~cm}$ ), and they had more ribs than the $\mathrm{CH}$ pigs ( $\mathrm{p}<0.001,14.50$ vs 13.10). Importantly, the carcasses of $B C$ pigs were more muscular than those of $\mathrm{CH}$ pigs $(\mathrm{p}<0.001)$, with a higher carcass lean meat composition (50.76\% vs $42.58 \%$ ), larger loin muscle area $\left(32.61 \mathrm{~cm}^{2}\right.$ vs $\left.24.15 \mathrm{~cm}^{2}\right)$, higher ham content $(29.98 \%$ vs $25.03 \%$ ), thinner back fat (26.44 $\mathrm{mm}$ vs $35.99 \mathrm{~mm}$ ), and lower carcass fat content (23.65\% vs $32.46 \%)$. Similar to $\mathrm{CH}$ pigs, $\mathrm{BC}$ pigs had thick skin $(5.77 \mathrm{~mm})$ and a high carcass skin rate $(14.93 \%)$.

\section{Meat quality and muscle fatty acid composition of} crossbred $\mathrm{BC}$ pigs compared with purebred $\mathrm{CH}$ pigs Lick to $\mathrm{CH}$ pigs, crossbred BC F4 pigs displayed excellent meat quality attributes (Table 6). The meat from $\mathrm{BC}$ pigs showed ideal $\mathrm{pH}$ value $\left(\mathrm{pH}_{45 \text { min }} 6.32\right.$ and $\left.\mathrm{pH}_{24 \mathrm{~h}} 5.90\right)$ and meat-color parameter $\left(\mathrm{L}_{45 \text { min }} 39.68\right.$ and $\left.\mathrm{L}_{24 \mathrm{~h}} 42.41\right)$; meanwhile, the meat from $\mathrm{BC}$ pigs had strong water-holding capacity, with less water content (72.64\%), very low drip loss (1.68\%) and cooking loss (29.06\%). Notably, the BC meat contained high intramuscular fat (IMF) content similar to $\mathrm{CH}$ pigs 
Table 5. Growth and carcass traits of crossbred BC F4 pigs compared with purebred $\mathrm{CH}$ pigs

\begin{tabular}{|c|c|c|c|c|c|c|c|c|}
\hline \multirow{3}{*}{ Traits } & \multicolumn{6}{|c|}{ Breeds } & \multirow{3}{*}{ SEM } & \multirow{3}{*}{ p-value } \\
\hline & \multicolumn{3}{|c|}{$B C^{1)}(n=60$ and 30$)$} & \multicolumn{3}{|c|}{$\mathrm{CH}^{2)}(\mathrm{n}=60$ and 30$)$} & & \\
\hline & Mean & SD & CV (\%) & Mean & SD & CV (\%) & & \\
\hline Daily live weight gain (g/d) & 645.28 & 30.02 & 4.65 & 447.11 & 42.72 & 9.55 & 10.44 & 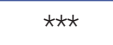 \\
\hline Feed-to-gain ratio (kg/kg) & 3.06 & 0.18 & 5.88 & 4.03 & 0.36 & 8.93 & 0.09 & $\star \star \star$ \\
\hline Slaughter age (day) & 211.70 & 4.07 & 1.92 & 302.05 & 4.82 & 1.60 & 1.41 & $\star \star \star$ \\
\hline Slaughter weight (kg) & 112.56 & 2.64 & 2.35 & 105.00 & 7.18 & 6.84 & 1.71 & 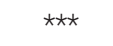 \\
\hline Carcass length (cm) & 83.35 & 1.80 & 2.16 & 74.85 & 3.38 & 4.52 & 0.86 & $\star \star \star$ \\
\hline Dressing percentage (\%) & 73.27 & 2.39 & 3.26 & 74.21 & 1.14 & 1.54 & 0.59 & n.s. ${ }^{2)}$ \\
\hline Back fat thickness (mm) & 26.44 & 3.56 & 13.46 & 35.99 & 3.52 & 9.78 & 1.12 & $\star \star$ \\
\hline Loin muscle area (cm2) & 32.61 & 6.24 & 19.14 & 24.15 & 3.99 & 16.52 & 1.66 & $\star \star \star ~$ \\
\hline Skin thickness (mm) & 5.77 & 0.87 & 15.08 & 6.03 & 1.15 & 19.07 & 0.41 & n.s. \\
\hline Number of ribs & 14.50 & 0.53 & 3.66 & 13.10 & 0.45 & 3.44 & 0.18 & $\star \star \star$ \\
\hline $\operatorname{Ham}(\%)$ & 29.98 & 1.64 & 5.47 & 25.03 & 1.39 & 5.55 & 0.48 & $\star \star \star$ \\
\hline Carcass lean (\%) & 50.76 & 2.95 & 5.81 & 42.58 & 2.39 & 5.61 & 0.85 & $\star \star \star$ \\
\hline Carcass fat (\%) & 23.65 & 2.54 & 10.74 & 32.46 & 2.49 & 7.67 & 0.92 & $\star \star \star$ \\
\hline Carcass skin (\%) & 14.93 & 1.02 & 6.83 & 14.66 & 1.68 & 11.46 & 0.54 & n.s. \\
\hline Carcass bone (\%) & 10.74 & 0.85 & 7.91 & 10.29 & 0.87 & 8.45 & 0.27 & n.s. \\
\hline
\end{tabular}

SEM, standard error of the mean; SD, standard deviation; $\mathrm{CV}$, coefficient of variation.

1) $\mathrm{BC}$, Berkshire $\times$ Chenghua; $\mathrm{CH}$, Chenghua.

2) n.s., not significant $(p>0.05)$

$\star \star p<0.01, * \star \star p<0.001$.

(3.72\% vs $3.80 \%)$. In addition, the BC pigs displayed ideal muscle fiber parameters, with a small myofiber area $(2,641.75$ $\left.\mu \mathrm{m}^{2}\right)$, low shear force $(6.16 \mathrm{~kg})$ and firmness $(26.59 \mathrm{~kg} / \mathrm{s})$.

More than 16 FAs were identified in the longissimus dorsi from both crossbred $\mathrm{BC} \mathrm{F} 4$ pigs and purebred $\mathrm{CH}$ pigs, and the most prevalent FAs in all pigs were C18:1, C16:0, C18:0 and $\mathrm{C} 18: 2$, accounting for more than $85 \%$ of all FAs (Table 7). The predominant saturated fatty acids (SFAs) were C16:0 and C18:0 in all pigs, while total concentrations of SFAs ac- counted for $34.14 \%$ in $\mathrm{BC}$ pigs and $49 \%$ in $\mathrm{CH}$ pigs. The predominant monounsaturated fatty acid (MUFA) in all pigs was $\mathrm{C} 18: 1$ (52.48\% for $\mathrm{BC}$ and $41.41 \%$ for $\mathrm{CH}$ ). C18:2 was the main polyunsaturated fatty acid (PUFA) in all pigs, and the total concentrations of PUFA were significantly affected by breed, with $\mathrm{BC}$ pigs exhibiting a higher PUFA content than $\mathrm{CH}$ pigs ( $\mathrm{p}<0.05,14.03 \%$ vs $9.59 \%)$, which led to a PUFA:SFA ratio of 0.39 for $\mathrm{BC}$ crosses and 0.20 for $\mathrm{CH}$ pigs.

Table 6. Meat quality traits of crossbred BC F4 pigs compared with purebred $\mathrm{CH}$ pigs

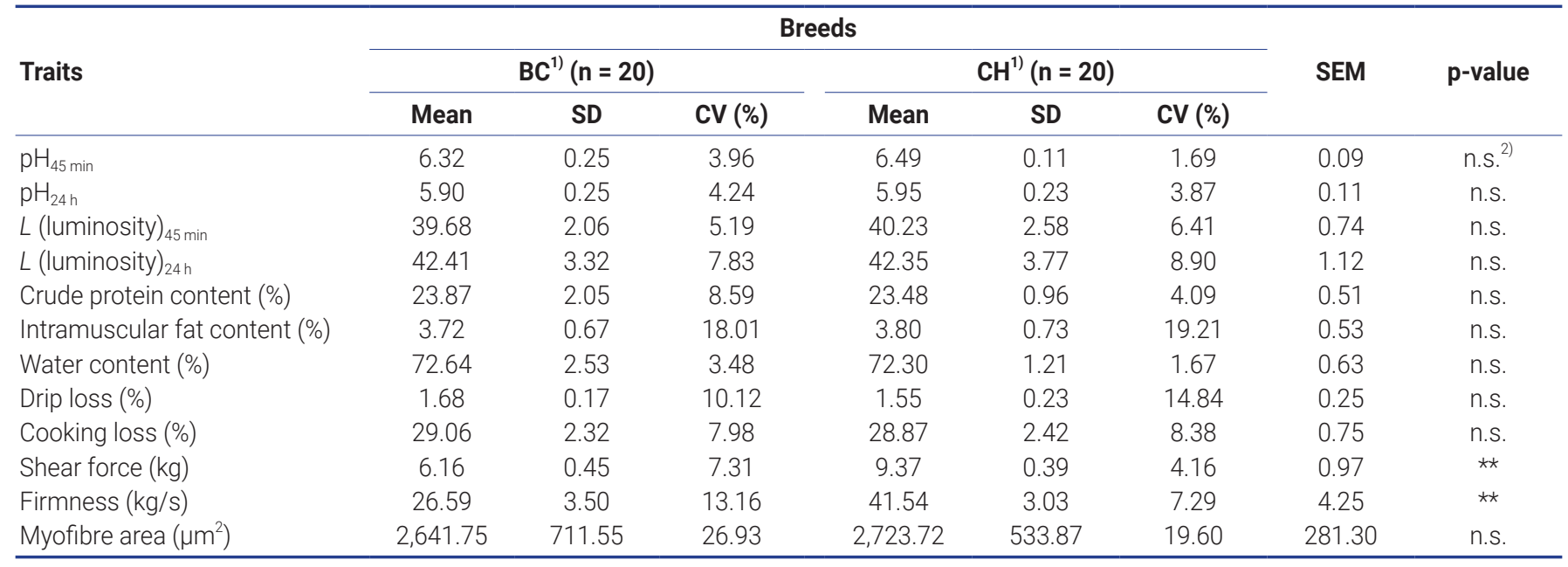

SEM, standard error of the mean; SD, standard deviation; $C V$, coefficient of variation.

1) $\mathrm{BC}$, Berkshire $\times$ Chenghua; $\mathrm{CH}$, Chenghua.

${ }^{2)}$ n.s., not significant $(p>0.05)$.

$\star \star p<0.01$. 
Table 7. Fatty acid composition of M. longissimus lumborum from crossbred BC F4 pigs compared with purebred CH pigs (\% total fatty acids)

\begin{tabular}{|c|c|c|c|c|c|c|c|c|}
\hline \multirow{3}{*}{ Traits } & \multicolumn{6}{|c|}{ Breeds } & \multirow{3}{*}{ SEM } & \multirow{3}{*}{ p-value } \\
\hline & \multicolumn{3}{|c|}{$B C^{1)}(n=20)$} & \multicolumn{3}{|c|}{$\mathrm{CH}^{1)}(\mathrm{n}=20)$} & & \\
\hline & Mean & SD & CV (\%) & Mean & SD & CV (\%) & & \\
\hline C10:0 & 0.10 & 0.01 & 12.31 & 0.15 & 0.07 & 43.05 & 0.03 & n.s. ${ }^{2)}$ \\
\hline C12:0 & 0.08 & 0.01 & 7.61 & 0.1 & 0.02 & 22.74 & 0.01 & n.s. \\
\hline C14:0 & 1.59 & 0.14 & 8.91 & 1.48 & 0.22 & 15.17 & 0.11 & n.s. \\
\hline C16:0 & 14.93 & 0.67 & 4.47 & 28.22 & 3.6 & 12.77 & 1.64 & $\star \star *$ \\
\hline C16:1 & 4.01 & 0.22 & 5.43 & 3.93 & 1.02 & 26.06 & 0.47 & n.s. \\
\hline C17:0 & 0.15 & 0.02 & 14.91 & 0.21 & 0.04 & 16.87 & 0.02 & $\star \star$ \\
\hline C18:0 & 16.08 & 0.51 & 3.15 & 12.53 & 1.76 & 14.03 & 0.81 & $\star \star \star$ \\
\hline C18:1n9c & 45.13 & 3.72 & 8.23 & 36.26 & 8.48 & 23.39 & 3.95 & * \\
\hline C18:2n6c & 11.95 & 2.19 & 18.29 & 8.21 & 2.47 & 30.07 & 1.23 & $\star \star$ \\
\hline C18:3n3 & 0.27 & 0.04 & 15.32 & 0.25 & 0.04 & 15.69 & 0.02 & n.s. \\
\hline C20:0 & 0.25 & 0.04 & 14.28 & 0.29 & 0.07 & 23.71 & 0.03 & n.s. \\
\hline C20:2 & 0.39 & 0.07 & 18.14 & 0.61 & 0.24 & 39.76 & 0.11 & n.s. \\
\hline C20:3n3 & 0.44 & 0.08 & 19.01 & 0.27 & 0.09 & 34.25 & 0.01 & n.s. \\
\hline C21:0 & 0.81 & 0.05 & 6.47 & 4.05 & 6.59 & 162.72 & 1.11 & n.s. \\
\hline C22:1n9 & 3.33 & 0.69 & 20.61 & 0.03 & 0.01 & 24.77 & 0.16 & $\star \star \star$ \\
\hline C23:0 & 0.05 & 0.02 & 36.47 & 1.60 & 0.66 & 41.58 & 0.30 & $\star \star \star$ \\
\hline SFA & 34.14 & 1.22 & 3.56 & 49.00 & 6.69 & 13.66 & 3.05 & $\star \star \star \star$ \\
\hline PUFA & 14.03 & 11.39 & 81.19 & 9.59 & 2.84 & 29.67 & 1.41 & * \\
\hline MUFA & 52.48 & 3.14 & 5.99 & 41.41 & 8.3 & 20.05 & 3.84 & $\star \star$ \\
\hline MUFA:SFA ${ }^{3)}$ & 1.54 & 0.14 & 8.81 & 0.85 & 0.23 & 27.55 & 0.11 & $\star \star \star$ \\
\hline PUFA:SFA ${ }^{4)}$ & 0.39 & 0.07 & 16.79 & 0.20 & 0.05 & 26.13 & 0.03 & $\star \star \star$ \\
\hline
\end{tabular}

SEM, standard error of the mean; SD, standard deviation; CV, coefficient of variation; SFA, saturated fatty acid; PUFA, polyunsaturated fatty acid; MUFA, monounsaturated fatty acid.

1) $\mathrm{BC}$, Berkshire $\times$ Chenghua; $\mathrm{CH}$, Chenghua.

2) n.S., not significant ( $p>0.05)$.

3) MUFA:SFA, the ratio of MUFA to SFA;

4) PUFA:SFA, the ratio of PUFA to SFA.

${ }^{\star} p<0.05 ;{ }^{* *} p<0.01 ;{ }^{* \star *} p<0.001$.

\section{DISCUSSION}

\section{Black coat variation of pigs associated with the MC1R gene}

Coat color is an important characteristic of various pig breeds and color variations may be useful in identifying the components of some specific crossbreeding schemes as well as contributing to the image associated with high-quality regional products [12]. In these crossbreeding experiments between Chinese indigenous $\mathrm{CH}$ pigs (uniform black) and imported BK pigs (domino black spotting) yielded a "dominant black" coat color hereditary pattern. A similar result was reported in which the allelism between the "uniform black type" and "domino black spotting type" may also be inferred from Large Black $\times$ BK crossed pigs [13].

Our observed segregation results led to the important discovery that the coat color variation of crossbred BC pigs is determined by the single $M C 1 R$ gene, although more than eight color loci have been determined to be involved [14]. Twelve mutations were screened for the $M C 1 R$ gene in BC crosses, which represent two typical $E^{D 1}$ and $E^{P}$ alleles inferred according to the results of a previous report [11]. Our results indicate that the $E^{D 1}$ allele associated with a black coat phenotype is inherited in a dominant pattern in crossbred BC pigs. Consequently, we selected black boars and gilts genotyped with homozygous $E^{D 1} E^{D 1}$ from the F3 progeny and largely succeeded in producing the $\mathrm{BC}$ breed standard of black coat.

\section{Crossbreeding improves sow reproductive performance}

The level of sow productivity is one of the most important production traits affecting the efficiency of a swine enterprise [15]. Crossbreeding programs have been extensively used to improve reproduction by exploiting breed additive effects, breed maternal effects, and heterosis. Young [16] reported that Chinese indigenous breeds Meishan, Fengjing, and Minzhu pigs can be used to produce crossbred gilts that have a higher level of reproductive performance than Duroc crossbred gilts. In this study, we found that crossbred BC F4 gilts had a higher litter and tear size, and the $\mathrm{BC}$ gilts are heavier at farrowing and at weaning than purebred $\mathrm{CH}$ gilts. Notably, the mean of 12.36 pigs for total litter size and 11.64 pigs for alive litter size of $\mathrm{BC}$ sows offers an advantage in litter 
size during the breeding process. A similar result was reported in which the cross sows from Chinese native Meishan, Fengjing, and Minzhu pigs showed a total number of pigs born (12.0 to 11.0 pigs) and a number of pigs born alive (11.3 to 10.7 pigs) per litter [14].

A favorable mean age at puberty of $168 \mathrm{~d}$ for crossbred $\mathrm{BC}$ gilts was found although BC gilts reached puberty later than $\mathrm{CH}$ gilts. A similar result was reported for a mean age at puberty of 118 and $217 \mathrm{~d}$ for purebred Meishan and its crossbred gilts [17]. However, purebred Duroc pigs averaged $234 \mathrm{~d}$ at puberty, compared with 210, 205, and $201 \mathrm{~d}$ for Hampshire, Pietrain, and Spot pigs [18].

\section{Crossbreeding improves growth performance and carcass composition}

Previous reports revealed that the growth performance of hybrid pigs from Duroc $\times$ Dahe, Celta $\times$ Landrace, Celta $\times$ Duroc, and Duroc $\times$ Yanan was substantially improved compared with that of native pig breeds $[3,4,6]$. In our study, two important growth traits, weight gain and feed efficiency, were considerably improved in crossbred BC F4 pigs, indicating that the $\mathrm{BC}$ pigs reached a competitive slaughter age (approximately $180 \mathrm{~d}$ ) at above $100 \mathrm{~kg}$ slaughter weight.

Meanwhile, crossbred BC pigs exhibited improved carcass characteristics, such as a moderate lean meat ratio $(\sim 50 \%)$ and backfat thickness $(\sim 2.6 \mathrm{~cm})$. This result is similar to previous studies $[3,4,6]$, which reported that the carcass characteristics of hybrid pigs were greatly improved compared with those of the native pig breeds and a mean lean meat ratio of $51 \%$ to $55 \%$ was found in the crosses from Duroc $\times$ Dahe, Celta $\times$ Landrace, Celta $\times$ Duroc, and Duroc $\times$ Yanan. According to market demand for black pork in China, we suggest that it is perfectly suitable for black breeds to reach a mean of $53 \%$ to $55 \%$ for lean meat ratio (approximately 3\% to $5 \%$ increase). Therefore, to achieve an ideal lean meat ratio, we will select back fat further down to $20 \mathrm{~mm}$ for alive back fat thickness at $180 \mathrm{~d}$ of age in the subsequent breeding process of $\mathrm{BC}$ pigs.

\section{Breed affecting meat quality characteristics}

Meat quality is a key factor affecting how pork can be utilized. When choosing the best crossbreeding strategy, it is important to recognize pig breeds that determine meat quality attributes [19]. In this study, the crossbred BC and purebred $\mathrm{CH}$ pigs produced excellent meat-quality characteristics, which showed normal and high $\mathrm{pH}$ values compared to the recommended normal levels [20] $\left(\mathrm{pH}_{45 \min }>6.1\right.$ and $\mathrm{pH}_{24 \mathrm{~h}} 5.5$ to 6.0 ), normal and low meat color parameters according to NPPC standards (Minolta L-value levels of 37 to 49) [21], lower drip loss than those for foreign breeds above $3 \%$ [22], and smaller muscle-fiber areas than foreign hybrid pigs above $5,000 \mu \mathrm{m}^{2}$ [19].
As the single most important parameter of meat quality, the IMF content is related to the organoleptic characteristics of pig meat and influences meat and meat-product quality [23]. An IMF content of $2 \%$ to $3 \%$ is suggested to be optimal for food quality $[24,25]$. Interestingly, the crossbred BC pigs in the present study exhibited relatively high IMF content (3.72\%). Meanwhile, a higher PUFA:SFA ratio of IMF leads to better digestion rates and an improved digestibility of SFAs with emulsifying agents $[26,27]$ and the recommended PUFA:SFA ratio is more than 0.4 [28]. Here, a similar PUFA: SFA ratio of $\sim 0.39$ was found in the BC pigs. BC pig meat with a high IMF content and PUFA:SFA ratio can meet the demand for high-quality niche pork products.

The superior meat quality properties for the crossbred BC pigs may be attributed to the breed attributes of their parents. Previous studies found that the BK sire pigs are superior for loin meat and eating [22], and these characteristics are, consequently, thought to be attributed to their higher overall likeability score $[29,30]$ and improved acceptability compared with European commercial pork breeds [31]. Meanwhile, our results and those of a previous study indicate that $\mathrm{CH}$ pigs are also characterized by superior meat quality traits [1].

\section{CONCLUSION}

The coat color of Berkshire $\times$ Chenghua $(\mathrm{BC})$ cross pigs exhibits a "dominant black" phenotypic hereditary pattern and the new crossbred BC F4 pigs exhibit a uniform black coat pattern through proper selection of the sire and maternal pigs with the $E^{D 1} E^{D 1}$ homozygous genotype for the $M C 1 R$ gene. Meanwhile, the crossbred BC F4 pigs have an outstanding overall production performance, which shows that $\mathrm{BC}$ pigs have a relatively good maternal reproductive performance, market-competitive improved growth and carcass characteristics, and super meat-quality attributes. These results indicate that the new crossbred BC black pigs can be extensively used in commercial pig production to provide high-quality niche products.

\section{CONFLICT OF INTEREST}

We certify that there is no conflict of interest with any financial organization regarding the material discussed in the manuscript.

\section{FUNDING}

We thank the Qionglai Jialin Ecological Farm for animal experimental condition. This study was supported by the Key R\&D Program of Sichuan Province (2020YFN0018) and Chengdu Local Good Varieties of Livestock and Poultry Resources Protection and Exploitation and Utilization of 
Construction Projects.

\section{REFERENCES}

1. Qiao XQ. Preliminary study on the production performance and utilization prospect of local pig breeds in Sichuan Province. Sichuan Anim Vet Sci 1994;2:2-4 (in Chinese).

2. Tao X, Gu YR, Yang XM, et al. Study on the carcass performances of six local pig breeds of Sichuan Province. Swine Prod 2019;5:49-50 (in Chinese). https://doi.org/10.13257/ j.cnki.21-1104/s.2019.05.018

3. Jiang YZ, Zhu L, Li XW, Si T. Evaluation of the Chinese indigenous pig breed Dahe and crossbred Dawu for growth and carcass characteristics, organ weight, meat quality and intramuscular fatty acid and amino acid composition. Animal 2011;5:1485-92. https://doi.org/10.1017/S1751731111000425

4. Franco D, Vazquez JA, Lorenzo JM. Growth performance, carcass and meat quality of the Celta pig crossbred with Duroc and Landrance genotypes. Meat Sci 2014;96:195-202. https:// doi.org/10.1016/j.meatsci.2013.06.024

5. Muhlisin, Panjono, Lee SJ, Lee JK, Lee SK. Effects of crossbreeding and gender on the carcass traits and meat quality of Korean native black pig and duroc crossbred. Asian-Australas J Anim Sci 2014;27:1019-25. https://doi.org/10.5713/ajas. 2013.13734

6. Chen Y, Wei YY, Chen JN, et al. Growth, carcass characteristics and meat quality of Chinese indigenous Yanan pig crossbred with Duroc and Berkshire genotypes. Anim Prod Sci 2019; 59:1147-54. https://doi.org/10.1071/An17450

7. Rutledge JJ. Greek temples, tropical kine and recombination load. Livest Prod Sci 2001;68:171-9. https://doi.org/10.1016/ S0301-6226(00)00245-1

8. Fernández A, Toro M, Rodriguez C, Silio L. Heterosis and epistasis for teat number and fluctuating asymmetry in crosses between Jiaxing and Iberian pigs. Heredity 2004;93:222-7. https://doi.org/10.1038/sj.hdy.6800498

9. National Research Council (NRC). Nutrient requirements of swine.11th edn. Washington, DC, USA: National Academy Press; 2012.

10. Yang H, Ma C, Qiao F, Song Y, Du M. Lipolysis in intramuscular lipids during processing of traditional Xuanwei ham. Meat Sci 2005;71:670-5. https://doi.org/10.1016/j.meatsci.2005. 05.019

11. Kijas JM, Wales R, Tornsten A, Chardon P, Moller M, Andersson L. Melanocortin receptor 1 (MC1R) mutations and coat color in pigs. Genetics 1998;150:1177-85. https://doi.org/10.1093/ genetics/150.3.1177

12. Legault C. Genetics of colour variation. In: Rothschild MF, Ruvinsky A, editros. The genetics of the pig. Wallingford, UK: CAB International; 1998. pp. 51-69.

13. Carr-Saunders AM. Note on inheritance in swine. Science 1922;55:19. https://doi.org/10.1126/science.55.1410.19
14. Ollivier L, Sellier P. Pig genetics: a review. Ann Genet Sel Anim 1982;14:481. https://doi.org/10.1186/1297-9686-144-481

15. Tess MW, Bennett GL, Dickerson GE. Simulation of genetic changes in life cycle efficiency of pork production, II. Effects of components on efficiency. J Anim Sci 1983;56:354-68. https://doi.org/10.2527/jas1983.562354x

16. Young LD. Reproduction of F1 Meishan, Fengjing, Minzhu, and Duroc gilts and sows. J Anim Sci 1995;73:711-21. https:// doi.org/10.2527/1995.733711x

17. Christenson RK. Ovulation rate and embryo survival in Chinese Meishan and Occidental Crossbred females. In: Proceedings of the International Symposium on Chinese Pig Breeds. Harbin, China: Northeast Forestry University Press; 1992.

18. Young L, Dickerson G, Leymaster K. Performance of eight purebred and two composite swine populations. In: McAlhany M, editor. Series analytic: Swine Research Progress Report No. 3. ARS-US Department of Agriculture, Agricultural Research Service (USA); 1989.

19. Ruusunen M, Puolanne E, Sevon-Aimonen ML, Partanen K, Voutila L, Niemi J. Carcass and meat quality traits of four different pig crosses. Meat Sci 2012;90:543-7. https://doi. org/10.1016/j.meatsci.2011.09.010

20. Sellier P. Genetics of meat and carcass traits. In: Rothschild MF, Ruvinsky A, editros. The genetics of the pig. Wallingford, UK: CAB International; 1998. pp. 463-510.

21. National Pork Produces Council (NPPC). Pork composition and quality assessment procedures. 1st edn. Des Moines, IA, USA: NPPC; 2000.

22.Jones $\mathrm{G}$. Genetic aspects of domestication, common breeds and their origin. In: Rothschild MF, Ruvinsky A, editros. The genetics of the pig. Wallingford, UK: CAB International; 1998. pp. 17-50.

23. Wood J, Enser M, Moncrieff C, Kempster A. Effects of carcass fatness and sex on the composition and quality of pig meat. In: 34th International Congress of Meat Science and Technology; 1988: Brisbane, Australia. pp. 562-4.

24. Bejerholm C, Barton-Gade P. Effect of intramuscular fat level on eating quality of pig meat. In: Proceedings of the 32nd European meeting of meat research workers; 1986: Ghent, Belgium. pp. 389-91.

25.DeVol DL, McKeith FK, Bechtel PJ, Novakofski J, Shanks $\mathrm{RD}$, Carr TR. Variation in composition and palatability traits and relationships between muscle characteristics and palatability in a random sample of pork carcasses. J Anim Sci 1988;66:385-95. https://doi.org/10.2527/jas1988.662385x

26. Warnants N, Van Oeckel MJ, Boucque CV. Effect of incorporation of dietary polyunsaturated fatty acids in pork backfat on the quality of salami. Meat Sci 1998;49:435-45. https://doi. org/10.1016/s0309-1740(98)00011-4

27.Park SW, Seo SH, Chang MB, Shin IS, Paik IK. Evaluation of 
soybean oil as a lipid source for pig diets. Asian-Australas J Anim Sci 2009;22:1311-9. https://doi.org/10.5713/ajas.2009. 90104

28. Alonso V, Campo Mdel M, Provincial L, Roncales P, Beltran JA. Effect of protein level in commercial diets on pork meat quality. Meat Sci 2010;85:7-14. https://doi.org/10.1016/j. meatsci.2009.11.015

29. Wood JD, Brown SN, Nute GR, et al. Effects of breed, feed level and conditioning time on the tenderness of pork. Meat Sci 1996;44:105-12. https://doi.org/10.1016/s0309-1740(96)
00044-7

30.Wood JD, Richardson RI, Nute GR, et al. Effects of fatty acids on meat quality: a review. Meat Sci 2004;66:21-32. https:// doi.org/10.1016/S0309-1740(03)00022-6

31.Ellis M, Webb A, Avery P, Brown I. The influence of terminal sire genotype, sex, slaughter weight, feeding regime and slaughter-house on growth performance and carcass and meat quality in pigs and on the organoleptic properties of fresh pork. Anim Sci 1996;62:521-30. https://doi.org/10.1017/ S135772980001506X 